\title{
ОСОБЛИВОСТІ ФОРМУВАННЯ ІННОВАЦІЙНОЇ СТРАТЕГІЇ В СИСТЕМІ УПРАВЛІННЯ ЗОВНІШНЬОЕКОНОМІЧНОЮ ДІЯЛЬНІСТЮ ПІДПРИЕМСТВА
}

\author{
ОСОБЕННОСТИ ФОРМИРОВАНИЯ ИННОВАЦИОННОЙ СТАТЕГИИ В \\ СИСТЕМЕ УПРАВЛЕНИЯ ВНЕШНЕЭКОНОМИЧЕСКОЙ ДЕЯТЕЛЬНОСТЬЮ \\ ПРЕДПРИЯТИЯ
}

\section{FEATURES OF FORMATION OF INNOVATIVE STRATEGIES IN THE ENTERPRISE OF FOREIGN ACTIVITY MANAGEMENT}

В статті досліджено поняття інноващій та інноващійної стратегії у сфері управління та їх особливості для системи зовнішньоекономічної діяльності підприємства. Обгрунтовано необхідність та важливість застосування управлінських інновацій в системах управління зовнішньоекономічною діяльністю з метою забезпечення високих конкурентних переваг на зовнішньому ринку та підвищення прибутку. Визначено найбільш ефективні інновації в системі управління та иілі формування інноваційної стратегї $з$ удосконалення системи управління зовнішньоекономічною діяльністю підприємства. Визначено особливості, щзо притаманні управлінським інноваціям на зовнішньоторговельних підприємствах та стратегічні управлінські рішення, щзо мають лежати в основі розробки інноваційної стратегії. Проаналізовано основні чинники, які перешкоджають формуванню та впровадженню інновачійної стратегї в системі управління зовнішньоекономічною діяльністю. Наведено критерії оцінки ефективності реалізації управлінської інноваційної стратегії.

Ключові слова: управлінські інновації, інноваційна стратегія, система управління ЗЕД.

В статье исследованы понятия инноващий и инновачионной стратегии в сфере управления и их особенности для системь внешнеэкономической деятельности предприятия. Обоснована необходимость и важность применения управленческих инноваций в системах управления внешнеэкономической деятельностью с иелью обеспечения высоких конкурентных преимуществ на внешнем рынке и повышения прибыли. Определены наиболее эффективные инновачии в системе управления и цели формирования инновачионной стратегии по совершенствованию системы управления внешнеэкономической деятельностью предприятия. Определены особенности, присущие управленческим инновачиям на внешнеторговых предприятиях и стратегические управленческие решения, которые должны лежать в основе разработки инновационной стратегии. Проанализированы основные факторы, которые препятствуют формированию $u$ внедрению инновационной стратегии в системе управления внешнеэкономической деятельностью. Приведень критерии оценки эффективности реализации управленческой инновационной стратегии. 
Ключевые слова: управленческие инновации, инновационная стратегия, система управления ВЭД.

The article reviews the concept of innovation and innovation strategies in the management and their features for the system of foreign economic activity of the enterprise. Was justified the necessity and importance of management innovation in systems of foreign economic activity to ensure high competitive advantage in the international market and to increase profits. Were defined the most effective innovations in the management and goals forming of innovative strategies to improve the system of international management company. The features inherent in innovation management in foreign trade enterprises and strategic management decisions with underlie the development of innovative strategies. Were investigated the basic factors that prevent the formation and implementation of innovative strategies in the management of foreign economic activity. Was developed the criteria for evaluating the effectiveness of the implementation of management innovation strategy.

Keywords: management innovation, innovation strategy, the management system of FEA.

Вступ. В сучасному міжнародному середовищі існує безліч постійних та мінливих чинників, що негативно впливають на діяльність підприємств, які посилюються нестабільною економічною та політичною ситуацією, як в Україні так і за ії межами.

Діяльність будь-якої зовнішньоторговельної організації заснована на збереженні та укріпленні своїх позицій на національному та світовому ринках. В сучасних умовах традиційні засоби забезпечення конкурентоспроможності підприємства вже не здатні гарантувати довгострокові переваги на ринку.

В конкурентному ринковому середовищі керівництву зовнішньоторговельної компанії необхідно враховувати основні тенденції, які проявляються в розвитку бізнесу в останній період часу, а саме: зростання світової конкуренції; боротьба за різні види ресурсів та інвестиції; високий рівень інноваційності бізнес-процесів; прийняття складних рішень та забезпечення своєчасних та ефективних дій для їх реалізації.

Ключовим фактором досягнення високого рівня конкурентоспроможності підприємства $€$ гнучка та ефективна система управління, що швидко та якісно адаптується до динамічних змін зовнішнього середовища.

Організація управління ЗЕД $є$ інтегрованою частиною загальної системи управління підприємством, яка впливає на всі сфери діяльності підприємства та його подальший розвиток. Саме тому, формування інноваційної стратегії $\epsilon$ об'єктивною необхідністю для формування ефективної системи управління ЗЕД та всього підприємства.

Окремі питання формування інноваційної стратегії та дослідження сутності інновацій в системі управління підприємством висвітлені в роботах таких вчених як Момчева А. М. [1], Бальтюкевич В.В. [2], 
Синявиинська I.M. [3], Геник О. И. [4], Мартишевська Е.А. [5], Шаповал Е.А., Фоменко С.С. [6], Добринін В.С. [7] та інші.

Незважаючи на значне число публікацій, присвячених різним аспектам інновацій в системі управління підприємством, слід зазначити, що в них недостатньо досліджені особливості формування та впровадження даних інновацій на підприємствах, що займаються ЗЕД.

Постановка завдання. Головною метою даного дослідження $\epsilon$ визначення особливостей управлінських інновацій та формування інноваційної стратегії в системі управління зовнішньоекономічною діяльністю підприємства.

Методологія. В процесі дослідження були використані такі методологічні прийоми як порівняння та узагальнення, метод аналогії, метод систематизації. Інформаційна база складається з вітчизняних та зарубіжних наукових публікацій.

Результати дослідження. Інноваційна стратегія в системі управління діяльністю підприємства передбачає створення нової управлінської технології, нового бізнес-процесу або нової системи організації та управління. Нововведення створюється завдяки реформуванню існуючих управлінських систем, технологій та процесів.

Управлінські інновації часто випадають 3 точки зору керівників, які, зазвичай, зводять розвиток підприємства до технічних чи технологічних інновацій. Потенціал організації сприймається однозначно як технічний i технологічний. Організаційний $\mathrm{i}$ кадровий потенціали, тобто ступінь нарощування можливостей за рахунок більш ефективного управління i використання людських ресурсів, серйозно не використовуються. Таким чином, можливості для розвитку істотно знижуються.

Вважається, що найвища позиція в бізнесі досягається не стільки компаніями, що зробили прорив в прикладних дослідженнях, скільки компаніями 3 високим рівнем професіоналізму i “ноу-хау” в області менеджменту [6]. Не дивлячись на високі ризики проектів в області управлінських інновацій, вони $є$ для компаній набагато дешевшими, ніж технологічні або продуктові інновації.

Найбільш ефективними інноваціями в системі управління вважаються [7]: реінжиніринг або оптимізація бізнес-процесів, функціонально-вартісний аналіз, маржинальний аналіз, побудова клієнтоорієнтованої компанії, активний і агресивний маркетинг, корпоративні інформаційні системи, логістичне адміністрування, збалансована система показників ефективності, аутсорсинг, бенчмаркинг, механізми саморозвитку, п’ятиступінчаста модель мотивації та ін.

Система управління ЗЕД підприємства - це комплекс взаємопов'язаних і взаємозалежних елементів управління на підприємстві і власне зв'язків, які 
реалізують цілі підприємства на зовнішніх ринках, а також забезпечують вирішення його проблем у сфері зовнішніх ринків і пов'язаних з ними.

Інноваційні зміни $\epsilon$ особливо важливими в системі управління зовнішньоекономічною діяльністю підприємства, оскільки саме відділ ЗЕД більшою мірою забезпечує, організовує та контролює даний вид діяльності). Саме від ефективності роботи відділу залежить прибутковість, оперативність та ефективність здійснення підприємством експортно-імпортних операцій. Тим паче, якщо зовнішньоторговельна діяльність $\epsilon$ основним джерелом прибутку для підприємства.

Формування інноваційної стратегії в системі управління ЗЕД підприємства є досить складним і тривалим процесом, адже інновації в системах управління характеризуються високим ризиком, який науковці пояснюють психологічним бар'єром та уникненням невизначеності з боку персоналу, адже ця група нововведень в першу чергу стосується саме їх. Для даного типу інновацій в більшій мірі, ніж для технологічних та виробничих властивий ризик виникнення опору 3 боку працівників підприємства, несприйняття нових ідей.

Модель виникнення та розвитку інновацій в сфері управління можна описати за допомогою наступних етапів: усвідомлення проблеми, розробка та формулювання ідеї, іiі визнання.

В основі розробки інноваційної стратегії мають лежати стратегічні управлінські рішення, які [4]:

- орієнтовані на майбутнє і на постійні зміни середовища;

- пов'язані із залученням значних матеріальних ресурсів, широким використанням інтелектуального потенціалу;

- характеризуються гнучкістю, здатністю адаптуватися до змін ринкових умов;

- $\quad$ враховують неконтрольовані організацією зовнішні чинники.

Розробка інноваційної стратегії передбачає іiі формалізацію у вигляді інноваційної програми. При цьому повинні бути встановлені цілі, задачі, процедури в рамках інноваційних проектів, що включені в програму. Необхідно визначити ресурси i часові обмеження, як для окремих інноваційних проектів, так i для всієї інноваційної програми. Для організаційного забезпечення виконання програми необхідно сформувати організаційну структуру управління інноваціями всередині відділу зовнішньоекономічної діяльності, створити систему зовнішніх зв'язків 3 партнерами, споживачами та іншими зацікавленими сторонами.

Впровадження інноваційної стратегії потребує наявності відповідних організаційних та управлінських можливостей. Основна їх функція нівелювати негативний вплив від протидії змінам, які здебільшого виникають у найуспішніших підприємствах. Стійкість підприємства призводить до його 
негнучкості та нездатності розвивати внутрішні радикальні пропозиції, які $€$ основою інноваційної діяльності [3]. У вітчизняних зовнішньоторговельних підприємствах проблеми доповнюються бажанням зберегти стабільність у досить хиткому зовнішньому середовищі, оскільки керівництво не готове до ризику, що виникає.

Автори виділяють такі цілі формування інноваційної стратегії 3 удосконалення системи управління ЗЕД підприємства $[1,6]$ :

- $\quad$ формування бізнес-процесу ЗЕД, що є єдиним для всієї компанії;

- підвищення продуктивності праці і кількості завдань, що виконуються відділом ЗЕД;

- $\quad$ підвищення мотивації співробітників відділу ЗЕД;

- $\quad$ зменшення ризиків підприємства, що пов'язані з роботою відділу ЗЕД;

- підвищення кваліфікації співробітників відділу ЗЕД;

- $\quad$ підвищення мотивації співробітників відділу ЗЕД;

- $\quad$ організація більш прозорої схеми ЗЕД підприємства та окремих іiі ділянок;

- $\quad$ розширення ЗЕД підприємства, налагодження стосунків з новими контрагентами;

- $\quad$ автоматизація системи управління ЗЕД підприємства.

Оскільки зовнішньоекономічна діяльність нерозривно пов'язана 3 міжнародною торгівлею, експортом та імпортом продукції та сировини, формування інноваційної стратегії в системі управління такою діяльністю має певні особливості.

Перш за все - це неможливість передбачити наслідки реалізації інноваційної стратегії в мінливому зовнішньому середовищі діяльності підприємства. Також, управлінські зміни в сфері ЗЕД потребують підвищення кваліфікації персоналу, залучення зовнішніх, навіть міжнародних експертів, що потребує значних фінансових витрат та часу. Впровадження у відділі ЗЕД новітнього програмного забезпечення та повна комп'ютеризація роботи без сумніву $\epsilon$ дорого вартісною. Зміна структури управління на зовнішньоторговельному підприємстві також має свою специфіку.

Основними чинниками, які перешкоджають формуванню та впровадженню інноваційної стратегії в системі управління ЗЕД на підприємствах, $є$ :

- відсутність в достатньому обсязі фінансових можливостей для формування управлінського потенціалу;

- $\quad$ недостатня кваліфікація управлінського персоналу;

- відсутність інформації про ефективні нововведення у сфері управління ЗЕД та можливості одержати кваліфіковану допомогу i консультації. 
Ефективність інноваційної стратегії в системі управління ЗЕД виявляється у зростанні прибутку підприємства, збільшення частки зовнішнього ринку та конкурентоспроможності, підвищення результативності бізнес-процесів, зниження витрат, зростання рівня задоволення споживачів та персоналу.

Висновки. Отже, у статті було досліджено особливості формування інноваційної стратегії в системі управління підприємством, і зокрема системи управління зовнішньоекономічною діяльністю. Проведене дослідження дає змогу стверджувати, що правильно розроблена і обгрунтована інноваційна стратегія відіграє надзвичайно важливу роль у подальшому розвитку підприємства. Інноваційні перетворення системи управління ЗЕД призведуть до підвищення кваліфікації, мотивації та продуктивності праці персоналу зайнятого в забезпеченні зовнішньоекономічної діяльності, дозволять здійснити успішний пошук нових закордонних та вітчизняних ринків збуту, розширити зовнішньоекономічні операції через збільшення кількості контрагентів, збільшити прибутки підприємства. Звичайно, формування та реалізація управлінської інноваційної стратегії потребує значних витрат часу та коштів, але позитивні наслідки правильно проведеної роботи компенсують та значно перевищать вкладені ресурси.

Науковою новизною даного дослідження $є$ визначення особливостей та перешкод формування та впровадження управлінських інноваційних стратегій в зовнішньоторговельних підприємствах.

Подальші дослідження будуть стосуватись детального вивчення видів інноваційних стратегій, що можуть бути використані в системі управління зовнішньоекономічною діяльністю та можливості їх реалізації на підприємствах України.

\section{Лiтература:}

1. Момчева А. М. Управлінські інновації: сутність, види, особливості впровадження/ А. М. Момчева // Східноєвропейський національний університет імені Лесі Українки, Україна - 2011. - Вип. 23

2. Бальтюкевич В.В. Формування інноваційної стратегії підприємства / В.В. Бальтюкевич // Праці Одеського політехнічного університету - 2011. - Вип. 2(36)

3. Синявська I.M Формування інноваційної стратегії аграрного підприємства / Синявська I.M // Вісник Миколаївського державного аграрного університету - 2010.

4. Геник О. Особливості інноваційної стратегії організації вітчизняних підприємств / О. Геник // Формування ринкової економіки в Україні. - 2009. - Вип. 19. - С. 165-169.

5. Мартышевская Е.А. Разработка инновационной стратеги развития предприятия / Е.А. Мартышевская // Управление в социальных и экономических системах : м-лы XXI междунардной научно-практической конференции, г. Минск, 15 мая 2012 г. / Минский ин-т управления ; редкол.: Н.В. Суша [и др.]. - Минск, 2012. - С. 39-40.

6. Шаповал С.С., Фоменко Г.С. Управлінські інновації як головний чинник реструктуризації підприємств - суб'єктів зовнішньоекономічної діяльності / С.С. 
Шаповал, Г.С. Фоменко // Труды Одесского политехнического университета, 2009, вып. 1 Г.

7. Добрынин, В.С. Организация внедрения управленческих инноваций на промышленном предприятии: Автореф. дис.... канд. экон. наук: 08.00.05 / В.С. Добрынин; Гос. акад. проф. переподгот. И повышения квалификации руководящих работников и специалистов инвестицион. сферы. - М., 2008. - 22 с. 